\title{
The VP1u of Human Parvovirus B19: A Multifunctional Capsid Protein with Biotechnological Applications
}

\author{
Carlos Ros* (D), Jan Bieri (1) and Remo Leisi \\ Department of Chemistry and Biochemistry, University of Bern, 3012 Bern, Switzerland; \\ jan.bieri@dcb.unibe.ch (J.B.); remo.leisi@dcb.unibe.ch (R.L.) \\ * Correspondence: carlos.ros@dcb.unibe.ch \\ Academic Editor: Giorgio Gallinella \\ Received: 2 December 2020; Accepted: 16 December 2020; Published: 18 December 2020
}

\begin{abstract}
The viral protein 1 unique region (VP1u) of human parvovirus B19 (B19V) is a multifunctional capsid protein with essential roles in virus tropism, uptake, and subcellular trafficking. These functions reside on hidden protein domains, which become accessible upon interaction with cell membrane receptors. A receptor-binding domain (RBD) in VP1u is responsible for the specific targeting and uptake of the virus exclusively into cells of the erythroid lineage in the bone marrow. A phospholipase $\mathrm{A}_{2}$ domain promotes the endosomal escape of the incoming virus. The VP1u is also the immunodominant region of the capsid as it is the target of neutralizing antibodies. For all these reasons, the VP1u has raised great interest in antiviral research and vaccinology. Besides the essential functions in B19V infection, the remarkable erythroid specificity of the VP1u makes it a unique erythroid cell surface biomarker. Moreover, the demonstrated capacity of the VP1 $u$ to deliver diverse cargo specifically to cells around the proerythroblast differentiation stage, including erythroleukemic cells, offers novel therapeutic opportunities for erythroid-specific drug delivery. In this review, we focus on the multifunctional role of the VP1u in B19V infection and explore its potential in diagnostics and erythroid-specific therapeutics.
\end{abstract}

Keywords: parvovirus B19; B19V; VP1u; receptor; $\mathrm{PLA}_{2}$; virus entry; erythroid cells; biomarker; drug delivery; nanocarrier

\section{Introduction}

The Parvoviridae is a family of nonenveloped viruses that packages a linear, single-stranded DNA genome $(\sim 5 \mathrm{~kb})$ within a small $(\sim 25 \mathrm{~nm})$ icosahedral capsid. As a direct consequence of their limited coding potential, parvoviruses are particularly dependent on host cellular factors for their replication [1,2]. Parvoviruses are widely spread in nature and their host range might span the entire animal kingdom [3]. Depending on their host, members of the family Parvoviridae are subdivided into the subfamilies Parvovirinae, infecting vertebrates and Densovirinae, infecting insects and other arthropods. Viruses that infect vertebrates, including humans, are further divided into the dependoparvoviruses and the autonomous parvoviruses [4]. The dependoparvoviruses replicate only in the presence of a helper virus, such as adenovirus or herpesvirus. The adeno-associated viruses (AAVs) are not linked with any known pathology, have a wide tissue specificity, and replicate in dividing and nondividing cells. These properties make AAVs useful gene transfer vehicles for therapeutic applications [5]. Although autonomous parvoviruses use similar strategies for cell entry and replication, they differ substantially in their pathogenic potential, which ranges from subclinical to severe or even lethal infections [2]. As autonomous parvoviruses can only replicate in dividing cells, 
when the host cell DNA replication machinery becomes available, they tend to cause more severe infections in young than in adult hosts.

While most ssDNA viruses show a circular genome structure, parvoviruses have a linear genome, that is typically organized in two open reading frames (ORFs). The ORFs are flanked by palindromic sequences of variable length, which fold into hairpin structures and are essential for replication [6,7]. The $5^{\prime}$ ORF (ns or rep gene) encodes for the regulatory nonstructural protein(s) required for viral DNA replication and packaging. The 3' ORF (cap gene) encodes two to four variants of a single capsid protein (VP). Following a principle of genetic economy, the different VPs are generated by alternative splicing or alternative codon usage, but also by post-translational proteolytic processing during entry, resulting in a common C-terminal sequence but different $\mathrm{N}$-terminal extensions of variable length [8-10]. The $\mathrm{T}=1$ icosahedral parvovirus capsid is assembled from $60 \mathrm{VPs}$, however, the number of N-terminal VP variants used to assemble the infectious particles varies from two (VP1 and VP2) to four (VP1-VP4) depending on the genus. The VP variants are numbered in order of length, with VP1 being the largest variant. The common C-terminal region of the VPs forms the capsid shell, which consists of a conserved alpha-helix and a jelly roll motif containing eight antiparallel $\beta$-strands. The different configurations of the loops connecting the conserved $\beta$-strands delineate the surface topology, which is characteristic to each parvovirus genus and define the virus tropism and antigenicity [11]. Despite low sequence identity, the parvovirus capsids display structural features that are conserved across different genera, i.e., a narrow depression at the twofold axis of symmetry, protrusions of variable size and shape at the threefold axis and a canyon-like structure encircling a cylindrical pore at the fivefold axis connecting with the interior of the capsid.

The minor protein VP1 has an N-terminal extension of variable length, the so-called VP1-unique region $(\mathrm{VP} 1 \mathrm{u})$, and is present at 3 to 10 copies per virion depending on the parvovirus genus. VP1 $\mathrm{u}$ is not required for virus assembly but contains several essential motifs required for the infection. Nuclear localization signals (NLSs) consisting of a stretch of basic amino acids have been identified in the VP1u from several parvoviruses. These motifs were shown to confer nuclear import potential to the incoming particles [12-19]. Another motif found in VP1u, except for amdoparvoviruses, is a phospholipase $A_{2}$ $\left(\mathrm{PLA}_{2}\right)$ enzyme domain, which enables viruses to escape from endosomal vesicles into the cytosol during cell entry [20-26]. Other motifs in VP1u were found to be essential for the infection. In AAV these motifs include signals that are known to be involved in protein interaction, endosomal sorting, and signal transduction in eukaryotic cells [27]. In B19V, a receptor-binding domain (RBD) required for virus uptake was identified at the N-terminal of the VP1u [28].

To infect the cell, parvoviruses follow an intricate path from the cell surface to the nucleus where they deliver the viral DNA for replication. During the process of entry, the incoming parvovirus capsids undergo a program of conformational rearrangements triggered by specific cellular factors that facilitate their intracellular transport [29,30]. A major capsid rearrangement that is largely conserved among parvoviruses involves the externalization of the VP1u region. Initially sequestered in mature virions, VP1u and its essential motifs become accessible at the particle surface during entry triggered by the acidic endosomal environment $[10,16,31]$. Besides low $\mathrm{pH}$, AAVs may require additional cellular factors [31]. An exception is B19V, whose VP1u becomes accessible during the initial interactions with cellular receptors [32]. VP1u exposure occurs through the five-fold channel that connects with the interior of the capsid [33-36]. Structural and in vitro studies suggest that these channels serve not only as portals for the externalization of N-terminal capsid protein sequences but also for the packaging and release of the viral genome [16,31,37-41]. Mutations that perturb the functional structure of the channel result in defective genome encapsidation, uncoating and VP1u externalization [38,42,43]. B19V represents again an exception as the VP1u seems to be already exposed on the capsid surface, although in a conformation that is not accessible to antibodies [44].

This review focuses on the VP1u of B19V, which shares common aspects with other parvoviruses but has unique features, like its structural conformation relative to the virion, immunodominance, extraordinary length or the presence of a receptor-binding domain responsible for the restricted tropism 
of the virus. We present the current knowledge on the different VP1u motifs, their functions in the virus infection and the potential biotechnological applications of the B19V VP1u in human therapy and diagnostics.

\section{Human Erythroparvovirus B19 (B19V)}

$\mathrm{B} 19 \mathrm{~V}$ is the most prominent and well-characterized human pathogen within the Parvoviridae causing a mild childhood rash disease named erythema infectiosum or fifth disease [45]. The infection is often asymptomatic; however, in adults, B19V infection may induce a wide range of more severe pathological conditions, such as arthralgias and arthritis [46]. B19V infection may lead to aplastic crisis in patients with pre-existing bone marrow disorders and shortened red cell survival [47] and persistent infection in immunocompromised persons. Infection during pregnancy may result in hydrops fetalis and fetal death [48]. B19V was the first parvovirus known to cause disease in humans [49]. Since 2005, other human parvoviruses have been identified and include human bocavirus (HBoV1-4), parvovirus 4, bufavirus, tusavirus and cutavirus. Except for $\mathrm{HBoV}$, which has been implicated in acute respiratory tract infections [50], the rest are emergent human parvoviruses with uncertain clinical significance [45,51].

$\mathrm{B} 19 \mathrm{~V}$ is transmitted via aerosol droplets that come into contact with the upper respiratory tract mucosa [47]. The virus crosses the mucosal epithelium through a yet unknown mechanism and disseminates with the bloodstream to the bone marrow, where it infects erythroid precursors at a particular erythropoietin (EPO)-dependent stage of differentiation [52-54]. The extraordinary narrow tropism of $\mathrm{B} 19 \mathrm{~V}$ is mediated at different levels of the viral life cycle. Crucial steps of the viral infection, such as uptake, genome replication, transcription, splicing and packaging, are restricted to the EPO-dependent erythroid differentiation around the proerythroblast stage [54-60]. The lytic replication cycle results in the destruction of the erythroid precursor cells [61,62], which accounts for the hematological syndromes observed during the infection [47]. Acute infection frequently results in high-titer viremia, which precedes the onset of clinical manifestations and has been associated with B19V transmission through transfusion and plasma-derived medicinal products [63].

\section{B19V Capsid}

The ssDNA genome of $\mathrm{B} 19 \mathrm{~V}$ is packaged into a small, nonenveloped, $\mathrm{T}=1$ icosahedral capsid. Similar to the genome of dependoparvoviruses, the B19V genome has two identical inverted terminal repeats (ITRs; $383 \mathrm{nt}$ ), which serve as the origin of replication [64]. The capsid consists of 60 structural subunits of two N-terminal VP variants, VP1 and VP2. Approximately 95\% are VP2 (major VP; $60 \mathrm{kDa}$ ) and 5\% are VP1 (minor VP; $86 \mathrm{kDa}$ ) [65]. VP1 and VP2 are generated through alternative splicing, resulting in the same C-terminal sequence but VP1 contains 227 additional residues at the VP1 N-terminal region, the so-called VP1 "unique region" (VP1u). The 60 protomers form 20 trimeric capsomers in the cytoplasm of the infected cell, which are assembled to an icosahedral capsid structure in the host nucleus. Due to the $\mathrm{T}=1$ symmetry, all protein subunits can be assembled in the same orientation to each other. This perfect symmetry enables an optimal thermodynamic sink for each protomer interaction, forming a very stable capsid around the ssDNA genome.

Large-scale propagation of native B19V is not possible due to the lack of a fully permissive cell culture system. Accordingly, structural studies have been performed with recombinant B19V-like particles, which are similar, although not identical, to infectious native capsids. The structure of the VP2 recombinant particle has been determined to $\sim 3.5 \AA$ resolution [36]. Similar to other parvoviruses and many icosahedral viruses, the major capsid protein VP2 is structured as a "jelly roll" with a $\beta$-barrel motif. The loops connecting the strands of the $\beta$-barrel define the capsid surface topology that differentiates B19V from other parvoviruses. B19V lacks the prominent protrusions at the icosahedral threefold axes characteristic in other parvoviruses. The channel at the fivefold icosahedral axis is surrounded by a large canyon-like depression. Different from other parvoviruses, the channel in B19 VP2 capsids is constricted at its outside end. However, a cluster of glycine residues at this position 
may confer sufficient flexibility to open the channel upon specific cellular triggers during the infection. A striking difference between B19V and other parvoviruses is the external position of the N-VP2 and probably also VP1u [36,66]. Accordingly, the role of the fivefold channel in B19V would be limited to the externalization and packaging of the viral genome.

\section{VP1u Is the Immunodominant Region of the Capsid but It Is Not Accessible in Native Virions}

Although VP1u may occupy a surface position in the B19V capsid, different regions of the protein were shown to be inaccessible to antibodies. However, exposure of native capsids to heat or low $\mathrm{pH}$ rendered these regions accessible without capsid disassembly. In contrast to native virions, VP1u is always accessible in recombinant B19V-like particles [44]. The inaccessibility of VP1u in native virions is not well understood and may be explained by a compact structural conformation, or by the presence of a masking structure hiding the essential protein domains to the immune system. Despite the non-accessible conformation of VP1u in native particles, this protein is the immunodominant part of the capsid and contains clusters of critical neutralizing epitopes [67,68] (Figure 1).

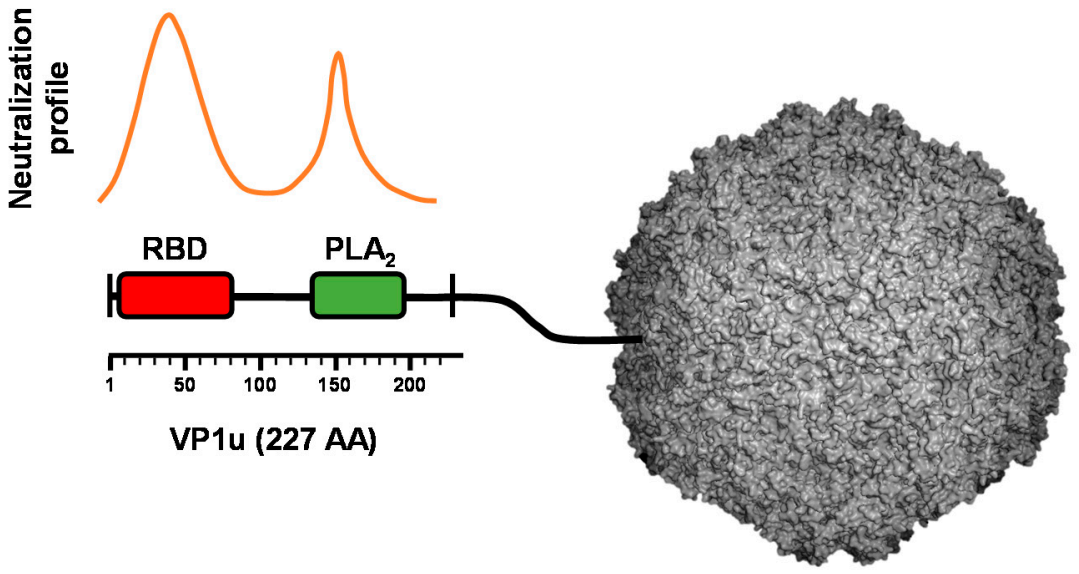

Figure 1. Schematic depiction of the neutralization profile and functional domains in the VP1u of B19V. The neutralizing profile revealed a cluster of important epitopes in the N-terminal region of the VP1 corresponding to functional domains. RBD; receptor-binding domain. PLA 2 ; phospholipase $\mathrm{A}_{2}$ domain.

Typically, neutralizing antibodies prevent the viral infection by interfering with early steps of the viral life cycle, i.e., attachment to cellular receptors, uptake, fusion, or conformational changes required for entry $[69,70]$. Importantly, the inhibition by neutralizing antibodies should be distinguished from the opsonization of viruses by antibodies, which can hamper the viral infection by immobilization of the virus and subsequent degradation of the immune complex by the complement system, immune cells or also by the cytoplasmic TRIM21/proteasome mechanism [71]. However, the specific targeting of essential capsid protein domains by neutralizing antibodies is required to efficiently interfere with the viral infection. Upon B19 viremia, the humoral immune response first generates IgM antibodies, which predominantly target the major capsid protein VP2. With the class-switch and long-term immunity, an increasing percentage of B lymphocytes secrete neutralizing antibodies against the $\mathrm{VP1}$ region [72]. In this regard, a deficient immune response to VP1u has been associated with persistent infections, emphasizing the important role of the immune response against VP1u in clearing the virus $[73,74]$.

Immunization experiments with vaccine candidates based on virus-like particles (VLPs) demonstrated that VP1u is essential to raise a strong neutralizing response against B19V [75,76]. However, the neutralization mechanism of antibodies targeting VP1u has remained largely elusive. Being the immunodominant region of the capsid, the originally inaccessible VP1u should become exposed in the extracellular milieu, and not inside endosomes, as shown for other parvoviruses. In line 
with this assumption, it has been shown that a neutralizing antibody against the N-terminal part of the VP1u was unable to bind native cell-free virions but was able to block virus entry into susceptible cells. Moreover, capsids without VP1u were unable to internalize into susceptible cells, demonstrating the involvement of the VP1u in B19V uptake [32,54]. These findings explain the high neutralization potential of VP1u antibodies, which target exclusively capsids during the initial interaction with cell receptors and block virus uptake, and further emphasize the importance of VP1u as an essential component of prospective B19V vaccines.

\section{Role of VP1u in the Restricted Tropism of B19V}

B19V has a remarkable narrow tropism. The virus shows productive infection exclusively in erythroid precursor cells at EPO-dependent intermediate erythroid differentiation stages, with increasing permissiveness from BFU-E to erythroblasts [53]. Viral tropism can be determined already at the cell surface by the expression of specific cell receptors required for virus entry and/or intracellularly by receptor-independent post-entry replication steps. The marked erythroid tropism of $\mathrm{B} 19 \mathrm{~V}$ is determined at multiple steps, i.e., the receptor-mediated uptake, genome replication, transcription, splicing and packaging $[56,57,77]$. A virus requiring such strict intracellular conditions for replication would also require a selective mechanism of cell entry to target exclusively the few cells where the virus can replicate. This strategy would allow the virus to avoid internalizing non-permissive cells, which would lead to abortive infections and inefficient viral propagation. Accordingly, it would be expected that B19V uses an erythroid-specific surface molecule as an entry receptor.

\subsection{VP1u Contains a Receptor-Binding Domain That Is Essential for Virus Entry into Permissive Cells}

The neutral glycosphingolipid globoside (Gb4), also known as P antigen, has long been considered the primary receptor of B19V [78]. A large body of evidence suggests that B19V recognizes Gb4 and that the interaction is required for the infection [79-82]. However, the wide-range Gb4 expression does not correlate well with B19V binding and uptake and cannot either explain the pathogenesis or the remarkable narrow tissue tropism of the virus [83]. By using a knockout cell line, we demonstrated that $\mathrm{Gb} 4$ does not have the expected function as the primary cell surface receptor required for B19V entry. Instead, Gb4 has an essential role at a post-entry step after virus uptake and before the delivery of the viral genome into the nucleus for replication [84]. Other receptor molecules, such as $\alpha 5 \beta 1$ integrin [85] and Ku80 autoantigen [86] have been proposed as potential coreceptors for B19V infection. However, the restricted uptake of $\mathrm{B} 19 \mathrm{~V}$ does not correspond with their wide expression profiles.

In an earlier study, we showed that the VP1u harbors a receptor-binding domain (RBD), which enables the uptake of the virus. Purified recombinant VP1u (recVP1u) was able to bind and to internalize exclusively into B19V permissive cells. Moreover, incorporation of VP1u subunits on bacteriophage VLPs by chemical coupling enabled their internalization into B19V permissive cells (Figure 2) [59]. The VP1u cognate receptor has not yet been identified, but its expression profile corresponds with the restricted tropism of B19V, being expressed exclusively in cells at erythropoietin-dependent erythroid differentiation stages [54,59].

\subsection{Mapping and Structural Characterization of the Receptor-Binding Domain in the VP1u}

The receptor-binding domain (RBD) in the VP1u was identified by using recVP1u variants with increasing N- and C-terminal truncations. The VP1u variants internalized normally when they were truncated less than $5 \mathrm{AA}$ at the $\mathrm{N}$-terminus or less than $147 \mathrm{AA}$ at the $\mathrm{C}$-terminus. Longer truncations at both ends decreased or blocked VP1u uptake [28]. According to these results, the RBD spans the region between AA 5-80 of VP1u, which explains the detectable exposure of this domain on the surface of susceptible cells before uptake [32,87], as well as the presence of a cluster of neutralizing epitopes [67,68]. 
A
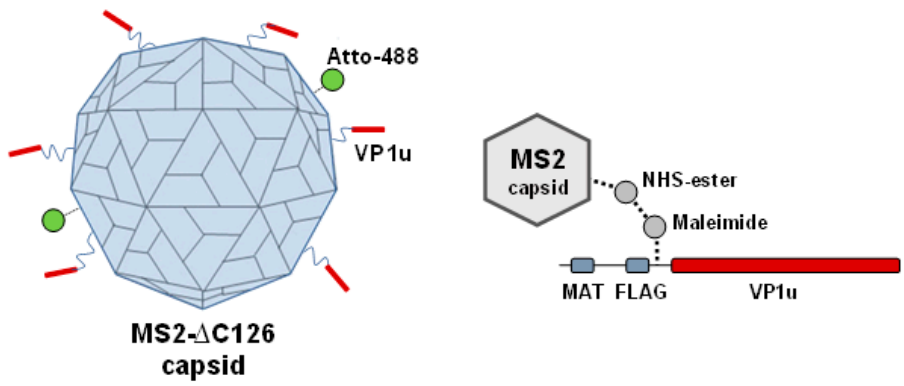

B

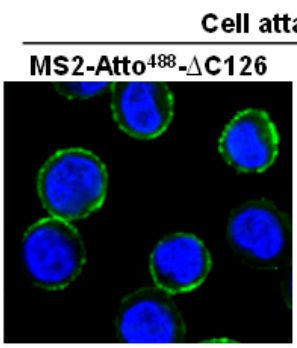

Cell attachment MS2-Atto ${ }^{488}$

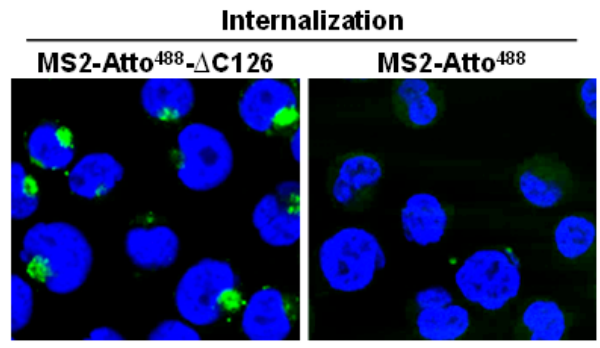

Figure 2. Binding and internalization of recombinant MS2-VP1u labeled with Atto-488. (A) Schematic depiction of MS2-VP1u particles. (B) Confocal fluorescence microscopy of MS2-VP1u bound to UT7/Epo cells at $4{ }^{\circ} \mathrm{C}$ and internalized at $37^{\circ} \mathrm{C}$. MS2-Atto ${ }^{488}-\Delta 126$ (100 N-terminal AA of VP1u); MS2-Atto ${ }^{488}$ (without VP1u).

The secondary structure analysis of the N-terminal of VP1u (AA 1-80) from natural B19V isolates, predicted a cluster of three $\alpha$-helices with high confidence: helix 1 (AA 14-31), helix 2 (35-45), and helix 3 (59-68) (Figure 3A). However, only helix 1 was conserved among other erythroparvoviruses (Figure 3B) and displayed a prominent amphiphilic character. The marked segregation of polar and hydrophobic amino acids between the two opposite flanks of the $\alpha$-helix is well suited for receptor binding. Compared with the residues of the hydrophilic side, the amino acids of the hydrophobic side were highly conserved (Figure 3C). Point mutations on the hydrophobic side blocked VP1u binding and internalization, suggesting a critical role of these residues in the interaction of VP1u with its cognate cellular receptor [28].

The sequence analysis of the first 80 amino acids of VP1u predicted two additional helices (Figure 3A). Disruption of the tertiary conformation of these domains by the introduction of flexible sequences strongly impaired VP1u internalization. This observation suggests that the spatial configuration of the three helices is crucial for VP1u binding to its cognate receptor and subsequent uptake. An ab initio modeling of the RBD by the QUARK algorithm [88] predicted a helix-like spatial configuration of the three helices (Figure 4A,B), where a cluster of conserved and internalization-relevant amino acids was modeled in close proximity (Figure 4C,D) [28]. The spatial proximity of function-relevant residues may correspond to a critical receptor-interacting site.

\subsection{VP1u Cognate Receptor Facilitates B19V Targeting and Uptake Exclusively into Permissive Cells}

B19V requires a strict intracellular environment for replication that can only be found in the erythroid progenitor cells (EPCs) in the bone marrow. The essential intracellular factors appear to be simultaneously upregulated in EPCs during the EPO-dependent differentiation stages. A study has shown that the internalization and the replication of B19V are considerably enhanced when CD34+ hematopoietic stem cells were stimulated with EPO [57]. Not surprisingly, the two cell lines that are most frequently used to study B19V infection, the megakaryocyte-erythroid UT7/Epo cells [89] and the erythroleukemic KU812Ep6 cells [90], are both derived from an EPO-dependent subclone. EPO signaling maintains the survival of cells that entered the intermediate erythroid differentiation stages [91-93]. Besides EPO signaling, B19V infection requires hypoxic conditions, which characterize the bone marrow microenvironment where the virus replicates. Hypoxia upregulates 
the signal transducer and activator of transcription 5 (STAT5) pathway, which facilitates viral DNA replication $[61,94,95]$. During the EPO-dependent differentiation stages, a cluster of erythroid-specific genes is upregulated [96], including the VP1u cognate receptor [59], which jointly are essential for $\mathrm{B} 19 \mathrm{~V}$ replication. In this regard, the main role of the VP1u receptor would be to facilitate the targeting and the uptake of $\mathrm{B} 19 \mathrm{~V}$ exclusively into cells providing a permissive intracellular environment for the infection. This strategy prevents the internalization into non-permissive cells, which would result in abortive infection.
A 1
1
$10 \quad 20$
30
40
$50 \quad 60$
$60 \quad 70$
80
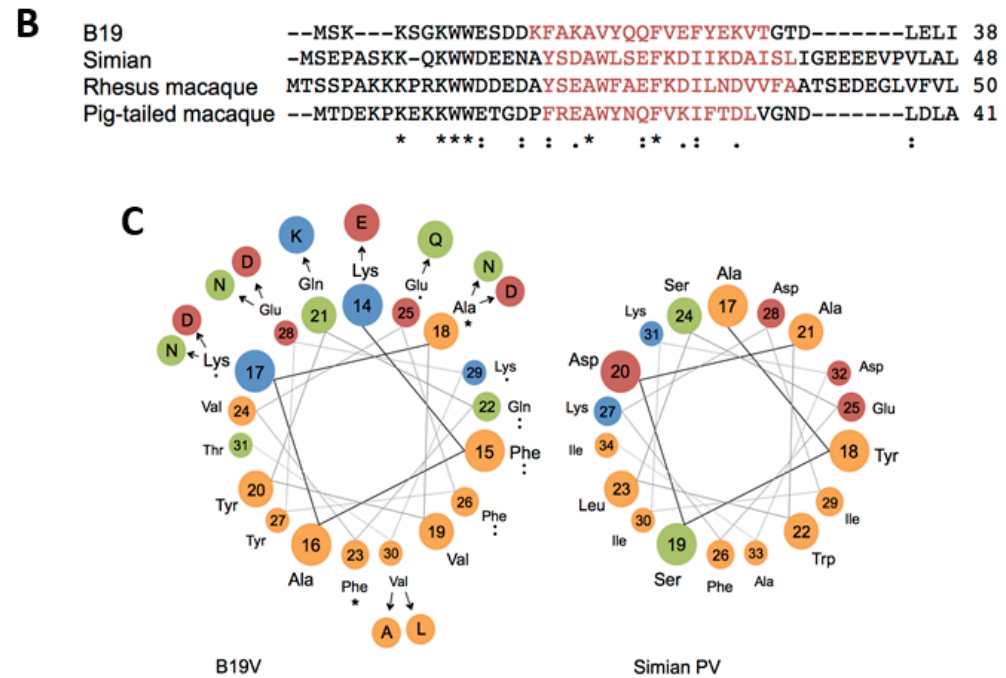

Figure 3. Structural motifs within the VP1u RBD. (A) Amino acid sequence of the N-terminal of VP1u (AA 1-80) and the three predicted alpha helices (underlined red). (B) Conservation of alpha helix 1 among erythroparvoviruses. (C) Modeled helical wheel of the conserved helix 1 (AA 14-31) shows the spatial arrangement of hydrophobic and polar amino acids within helix 1 . Amino acid differences found in B19V isolates are shown in a wider radius. Hydrophobic = orange; polar = green; basic = blue; acid $=$ red. The helical wheel of the simian parvovirus helix 1 is shown.
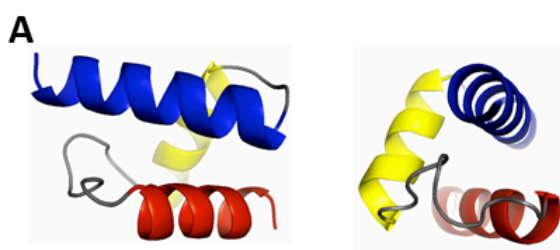

B
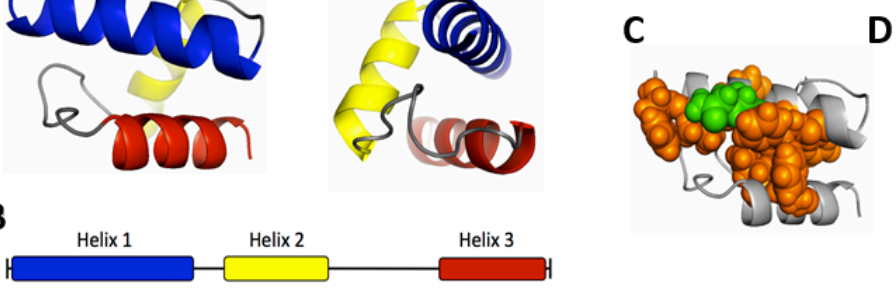

D

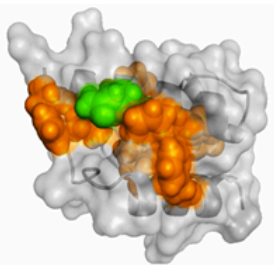

${ }^{14}$ EFAKAVY QOFVEFYEKVTGTDLELIQILKDHYNISLDNPLENPSSLFDLVARIKN ${ }^{6}$

Figure 4. Ab initio modeling of the RBD in the VP1u. (A) Front and side views. Helix 1 appears in blue (AA 14-31), helix 2 in yellow (AA 35-45), helix 3 in red (AA 57-68). (B) Helix distribution and sequence of the modeled AA 14-68. The amino acids required for VP1u internalization are colored in orange (hydrophobic) and green (polar). (C) The spatial distribution of essential amino acids is shown as spheres in the helical structure (D) and in the surface model of the RBD.

\subsection{Evolutionary Aspects of B19V Restricted Tropism and the Origin of the RBD in the VP1u}

The origin of the marked tropism of B19V for erythroid precursors in the bone marrow is not known. The erythroparvovirus and dependoparvovirus genomes show striking similarities, 
both having identical hairpin telomeres at both sides, and related replication mechanism [97]. It is conceivable that the erythroparvovirus ancestor was dependent on helper virus co-infections. In line with this hypothesis, several studies observed the enhancement of B19V replication and gene expression in non-permissive cells in the presence of helper virus genes [98,99]. Besides the enhanced genome replication, adenovirus genes transactivated the $\mathrm{B} 19 \mathrm{~V}$ promoters, including the $\mathrm{p} 44$ promoter in the middle of the genome (nt 2247), which is normally silenced during B19V infection [100,101]. The p44 promoter is homologous to the promoters that initiate the expression of the structural capsid proteins in other parvoviruses. Interestingly, the expression of the structural proteins represents a limiting factor in $\mathrm{B} 19 \mathrm{~V}$ infection in non-erythroid cells. The transcription of the structural genes from the $\mathrm{p} 44$ promoter might have played an important role in the helper-dependent ancestors of erythroparvoviruses but could have been replaced during evolution by an alternative helper-independent replication in erythroid cells. In contrast to most other parvoviruses, B19V shows alternative splicing in the transcript from the p6 promoter that also enables the expression of the distal genes [102]. This exceptional splicing mechanism of B19V, which strikingly occurs only in EPCs, makes the internal and helper-dependent p44 promoter dispensable. Interestingly, there is another putative internal promoter (p55) at nt 2308 that might have similar properties.

According to this evolutionary model (Figure 5), the erythroparvovirus ancestor would have generally exhibited a helper virus-dependent replication in different tissues, and sporadically, a helper-independent replication in EPCs. However, without a specific targeting and internalization into the erythroid progenitor cells, the overall infection still depended on the helper virus co-infection. The erythroid-specific transcription of the structural genes from the $\mathrm{p} 6$ promoter generates a transcript with a longer $5^{\prime}$-UTR that possibly allows the displacement of the start codon of the capsid proteins and consequently, a longer VP1u region (Figure 6). The additional $\mathrm{N}$-terminal amino acid sequence, expressed only during the helper-independent infection in erythroid cells, might have evolved to the RBD in the VP1u. The erythroid-specific targeting boosted the infection in the EPCs and thus represented a positive feedback loop that promoted the autonomous replication in the erythroid tissue. Vice versa, the helper-independent replication was the driving force for the positive feedback mechanism. The positive feedback enhanced the reliance on additional erythroid-specific factors and thus finally led to the extreme tropism of erythroparvoviruses.

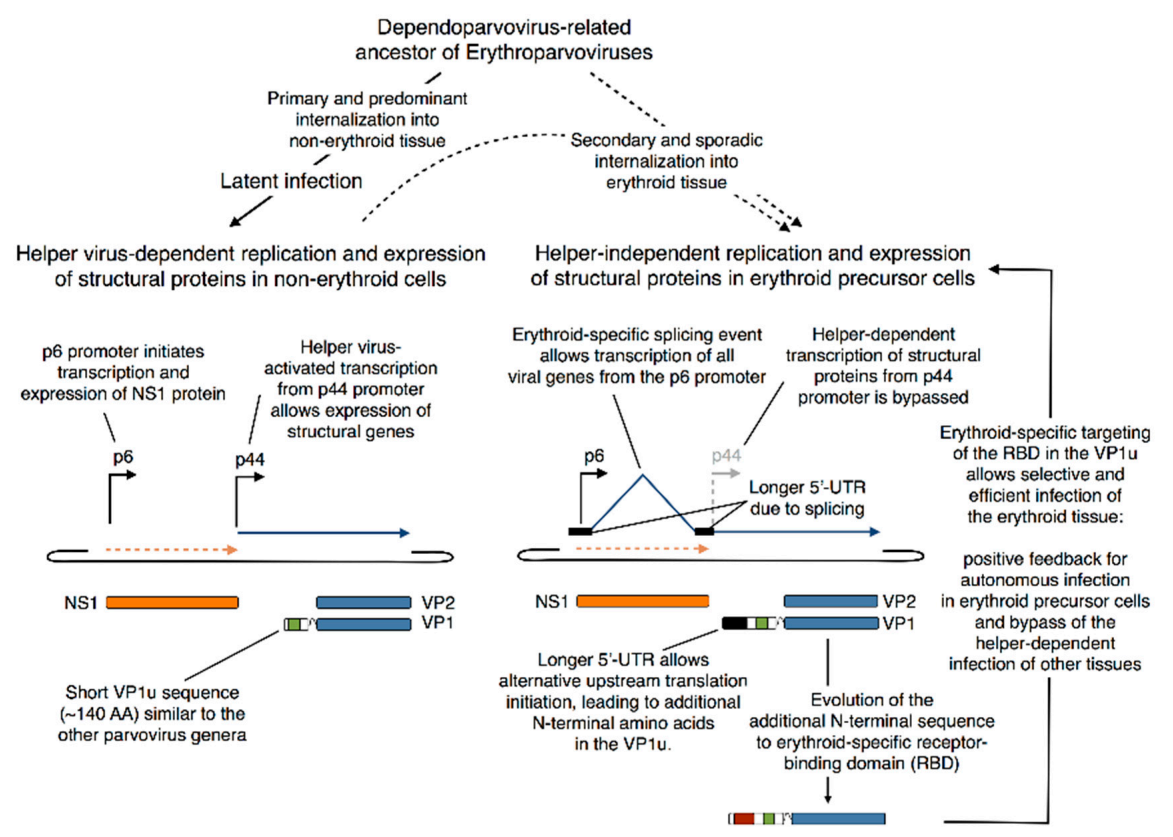

Figure 5. Proposed origin of the marked erythroid tropism of B19V (see text for details). 

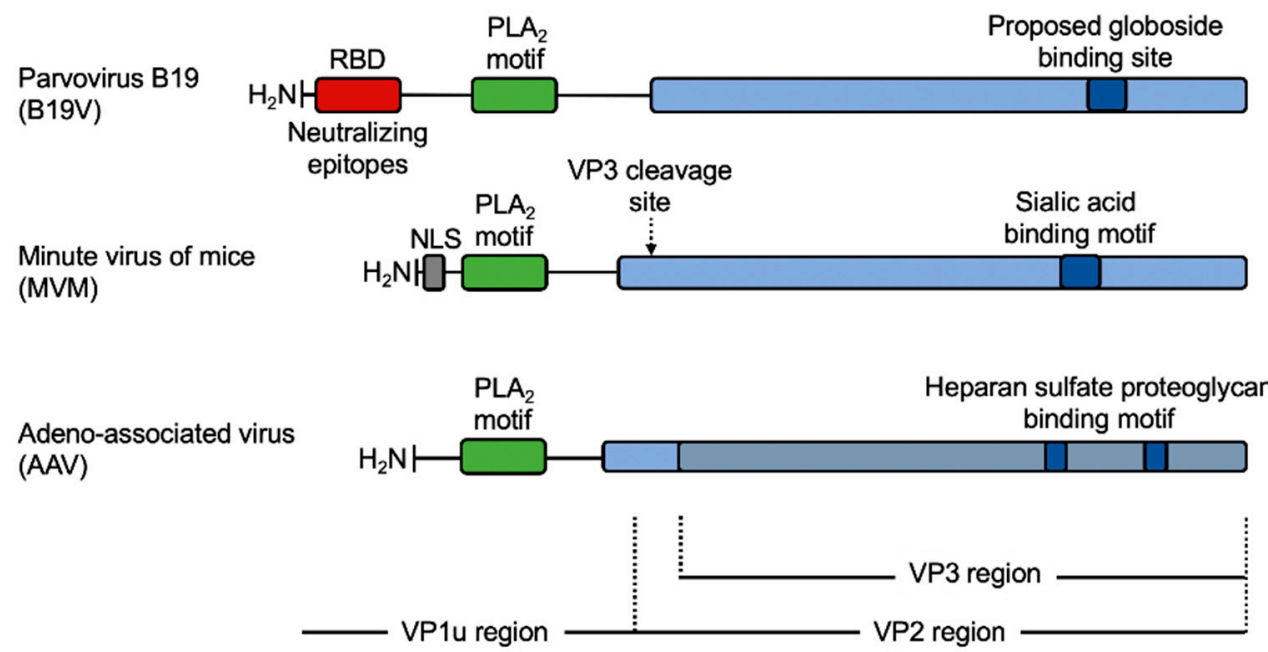

Figure 6. Infection-relevant functional domains in the structural proteins of three representative parvoviruses. B19V exhibits a longer VP1u region compared to other parvoviruses. The additional $\mathrm{N}$-terminal stretch of 80-90 amino acids contain the functional RBD [28] and a cluster of neutralizing epitopes $[67,68]$. NLS, nuclear localization signal.

The helper-dependent replication and expression of B19V genes in non-erythroid cells might still represent a significant aspect of the pathogenesis of B19V infection. The unspecific entry of the virus into non-erythroid tissues would not necessarily end in an abortive infection. The internalization of B19V during the late viremic phase by the antibody-dependent enhancement (ADE) provides a basis for latent infections in diverse tissues. These latent viruses might be sporadically reactivated by helper virus infections, which would explain many of the B19V-associated diseases as well as the recurrent detection of B19V DNA in the serum and different tissues $[99,103]$.

\section{Role of VP1u in the Subcellular Trafficking of Incoming B19V}

To infect the cell, parvoviruses follow a complex route from the plasma membrane to the nucleus where they replicate. Various domains in the VP1u of parvoviruses have been shown to play a critical role in the process by assisting the transport of the incoming capsids throughout the different membrane-enclosed organelles and the highly crowded cytosol and by promoting their translocation through the nuclear pore complex (NPC) into the nucleus (Figure 6).

\subsection{The Phospholipase $A_{2}\left(P L A_{2}\right)$ Domain}

Following the interaction of the VP1u RBD with its cognate receptor, B19V is internalized by clathrin-mediated endocytosis and enters the endosomal pathway [104]. Endosomes provide cues that trigger capsid conformational rearrangements required for subsequent trafficking steps and contribute to the transport of incoming viruses to the nuclear vicinity. However, the mechanism followed by parvoviruses to escape from endosomal vesicles into the cytosol remains unclear. Phospholipase $\mathrm{A}_{2}$ enzymes ( $\left.\mathrm{PLA}_{2} \mathrm{~s}\right)$ catalyze the hydrolysis of phospholipids and the release of lipid mediator precursors. Accordingly, $\mathrm{PLA}_{2} \mathrm{~s}$ are key enzymes in many cellular processes such as lipid membrane metabolism, inflammation, membrane remodeling, host defense, and signal transduction [105]. PLA $\mathrm{A}_{2} \mathrm{~S}$ are found in mammalian tissues as well as in arachnids, insects, mollusks, reptiles, plants, and bacteria.

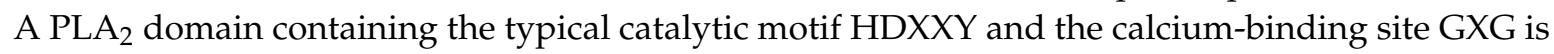
conserved in the VP1 $u$ of parvoviruses, including B19V (except for amdoparvoviruses) $[21-23,25,106]$. Mutations in either of these motifs disturbed both, the enzymatic activity and viral infectivity [20,21,23]. The pharmacological disruption of endosomal membranes or co-infection with endosomolytically active adenovirus, but not with inactive variants, partially rescued the infectivity of the PLA $\mathrm{P}_{2}$ mutants, suggesting a role of the VP1u PLA 2 in altering the endosomal membrane integrity to enable endosomal 
escape of viruses into the cytosol [24,26]. In B19V, VP1u mutations not related to the critical PLA 2 motifs were also shown to reduce the enzymatic activity, probably by disrupting the three-dimensional rearrangement surrounding the $\mathrm{PLA}_{2}$ domain [107]. Although the $\mathrm{PLA}_{2}$ may facilitate the endosomal escape of incoming B19V, the mechanism involved is poorly understood. Interestingly, B19V endosomal escape was shown to occur without detectable endosomal membrane permeabilization or damage [104] and the enzymatic requirements for the $\mathrm{PLA}_{2}$ activity, i.e., $\mathrm{pH}$ and calcium concentration are not optimal in the endocytic compartment [106]. Accordingly, it remains unclear how the PLA 2 activity of VP1 $u$ supports the escape of the endosomal capsids.

B19V PLA 2 has been shown to up-regulate $\mathrm{Ca}^{2+}$ entry [108], to inhibit $\mathrm{Na}^{+} / \mathrm{K}^{+}$ATPase activity and $\mathrm{K}^{+}$channels [109,110], and to up-regulate $\mathrm{ENaC}$ [111]. These activities may contribute to the pathophysiology of B19V infections. Moreover, due to the inflammatory-like effects exerted by recombinant VP1u in cultured fibroblast [112] and in UT7/Epo cells [107], it has been hypothesized that the PLA 2 domain of VP1u may contribute to B19V-associated syndromes, such as arthropathy and autoimmunity.

\subsection{Nuclear Localization Signals (NLSs)}

Following endosomal escape, parvovirus capsids are imported into the nucleus. Nuclear import of most proteins involves classical nuclear localization signals (NLSs) consisting of a stretch of basic amino acids, which interact with importin- $\alpha$ importin- $\beta$ to mediate transport through the nuclear pore [113]. The size of the parvovirus capsid is below the diameter limit of the nuclear pore complex (NPC). Therefore, capsids can theoretically be translocated through the NPC intact or without major disassembly [114]. NLSs have been identified in the VP1 $u$ from several parvoviruses [12-19] and confer nuclear import potential to the incoming particles via interaction with importin- $\beta$ [115]. The VP1u of B19V does not display a motif resembling a classical NLS, however, when expressed in eukaryotic cells, VP1u accumulates in the cytoplasm and in the nucleus [107]. The stretch of basic amino acids found in VP2 occupies an internal position in the capsid and has been implicated in the nuclear translocation of assembly intermediates [116]. Accordingly, the mechanism of nuclear import of B19V remains uncertain and might differ fundamentally from that of other parvoviruses.

\section{Biotechnological Applications of the VP1u of B19V}

Nanocarriers are designed to efficiently deliver therapeutic molecules to specific tissues minimizing adverse effects [117]. Despite important progress, the drug delivery technology based on synthetic nanocarriers remains highly inefficient. One meta-analysis revealed that over $99 \%$ of the drugs do not reach the diseased cells and accumulate instead in non-target tissues or are cleared from the body [118]. Ideally, nanocarriers must specifically internalize into the target cells, escape from the endocytic compartment, and release their payload into the cytosol. These processes resemble the early infection steps of viruses, which operate as powerful natural nanocarriers to efficiently deliver genetic material into target cells by complex mechanisms shaped by evolution. The targeting machinery that is engaged in the early viral infection steps can be utilized to generate virus-inspired nanocarriers as efficient drug or gene delivery vehicles [119,120]. In this regard, the VP1u of B19V includes many interesting features that can potentially be exploited for drug delivery and diagnostics, i.e., specific cell targeting, efficient cell entry, and endosomal escape.

\subsection{Specific Biomarker for EPO-Dependent Erythroid Differentiation Stages}

Diverse hematological conditions (e.g., leukemia, thalassemic and myelodysplastic syndromes, bone marrow metastases of solid tumors, septicemia, or severe health conditions after surgery) are typically associated with the presence of erythroblasts outside the bone marrow [121-126]. Accordingly, the screening of peripheral blood for nucleated red blood cells (NRBCs) is used to recognize hematological disorders or severe health conditions. Assays to detect NRBCs must be very sensitive because the presence of only a few NRBCs can indicate serious underlying disorders. 
Unfortunately, automated hematology analyzers may not detect low levels of NRBCs. Besides, they generate suspect flags, which should be examined manually [127]. The currently used automated detection of NRBCs in peripheral blood has a detection limit of 1-2 erythroblasts per 100 white blood cells $[123,128]$. In comparison, VP1u decorated MS2 capsids were able to detect as few as one erythroleukemic UT7/Epo cell in 100,000 isolated white blood cells (unpublished observations). The sensitive identification of erythroblasts in the peripheral blood by fluorescent VP1u bioconjugates has the potential to improve the detection of diverse hematological disorders or severe health conditions and to facilitate an early diagnosis without the systematic need of an invasive technique such as bone marrow biopsy.

The precise identification and isolation of erythroid progenitor cells is important in hematological research and in diagnostics to characterize and treat bone marrow disorders. However, the technique remains rather complex and laborious, since the currently used markers are not lineage-specific (CD36, CD38, CD44, CD45, CD71, CD105, EPOR) or are broadly expressed during the erythroid development (glycophorin A). Therefore, the combination of several antibodies is necessary to achieve the correct identification [124,129-134]. In contrast, the fluorescent VP1 $u$ bioconjugate appeared as a unique and highly sensitive marker for the EPO-dependent erythroid differentiation stages and readily detected these cells in heterogeneous cell populations from different tissues [54]. The findings show the potential of the VP1u as a biomarker to identify and sort erythroid differentiation stages in a simpler procedure than it has been practiced so far.

It is expected that the future biotechnological applications of the VP1u will be spurred by the identification of its cognate receptor. However, the identity of the VP1u receptor will not necessarily be determinant for the applicability of the VP1u as a specific cellular marker. Historically, it is not uncommon to use cell surface markers to identify cell populations based on empirical evidence without knowing the identity and/or the function of the targeted receptors.

\subsection{Specific Drug Delivery and Chemotherapy}

\subsection{1. $\beta$-Hemoglobin Disorders}

$\beta$-hemoglobin disorders are a group of highly prevalent hereditary diseases caused by mutations in the gene encoding for the $\beta$-chain of hemoglobin, resulting in qualitative and quantitative defects in $\beta$-globin production. $\beta$-thalassemias are a heterogeneous group of genetic disorders characterized by the partial or complete absence of $\beta$-globin chain production, leading to anemia and iron overload. The disease is highly prevalent with 80-90 million carriers worldwide. Without diagnosis and appropriate treatment, the severe forms of $\beta$-thalassemia lead to death before age 20 [135]. Sickle cell disease (SCD) is the most common and severe hemoglobinopathy. In SCD, a single mutation in the $\beta$-globin gene results in the production of an aberrant hemoglobin molecule, which causes the rigid sickle-like shape of erythrocytes. Without treatment, SCD is lethal before age five [136].

Patients with severe $\beta$-hemoglobin disorders require regular blood transfusions, which lead to iron overload and related complications. Accordingly, iron chelation therapies are also required [137,138]. The most severe forms of the disease have been successfully treated by allogeneic hematopoietic stem cell transplantation from a matched related donor. However, major drawbacks are the difficulty to find a histocompatible donor and the need for extensive immunosuppressive regimens, with the risk of immunological complication. Besides, this approach is not accessible for many affected individuals $[139,140]$. Gene therapy and gene editing strategies to restore the globin genes have generated promising results. However, these approaches lack cell-specific vectors, resulting in poor efficiency and the risk of insertional oncogenesis [141-143].

Due to the numerous drawbacks associated with the current therapeutic strategies, there is a great interest in developing novel therapeutic options. The therapeutic targeting of RNA by double-stranded RNA-mediated interference (RNAi) or by antisense oligonucleotides (ASOs) allows specific inhibition of the target of interest and a very rapid transferability to the clinics [144]. However, the delivery of 
nucleic acid molecules to the bone marrow remains highly inefficient. The MS2 capsid is a well-studied vector for drug delivery and can be easily loaded with therapeutic ASOs or small interfering RNAs (siRNA) [145,146]. This strategy provides protection of the therapeutic nucleic acid molecules in the extracellular milieu, avoids solubility problems, and thus allows more the options to improve the modifications of the oligonucleotides. In a previous study, we showed that anchoring of VP1u subunits to the surface of MS2 capsids retargets the particles to erythroid cells. This finding offers the opportunity to deliver encapsidated genetic material specifically to this cell population [59]. Potential targets of therapeutic ASOs or siRNA might be different factors involved in the regulation of erythropoiesis, such as transferrin receptor 2, or regulatory elements of fetal hemoglobin, such as B-cell lymphoma/leukemia 11A and erythroid Kruppel-like factor. Specific downregulation of such factors in erythroid progenitor cells would significantly alleviate symptoms of $\beta$-hemoglobin disorders [147-150].

\subsubsection{Erythroleukemia}

Acute erythroleukemia is a rare disorder associated with a poor prognosis. A study reported a median overall survival of 8 months [151]. The treatment of erythroleukemia is compromised due to the systemic distribution and resistance of the malignant cells to chemotherapeutics [152,153]. Therefore, the successful elimination of erythroleukemic cells by a cytotoxin requires a "magic bullet" strategy - an efficient and specific targeting of the toxin to cancer cells-minimizing adverse effects to the surrounding healthy cells [154]. Erythroleukemias exhibit proliferating cancer cells in the early and intermediate erythroid differentiation stages [155], which are the target cells of the VP1u. Accordingly, the VP1u-mediated toxin delivery represents a possible strategy to overcome the resistance of erythroleukemia to chemotherapeutics. In previous studies, VP1u successfully targeted a toxin specifically to malignant erythroid precursors and thus selectively eliminated these cells from a mixed cell culture [156].

The immunity of many individuals against B19V would represent a serious obstacle for the application of the VP1u-targeted delivery. About half of the human population is seropositive for anti-B19V antibodies. Similar problems are faced in the application of AAV vectors for gene therapy, where many individuals have antibodies against serotypes 2 and 3 [157]. Following the natural mechanism of viruses to evade the immune system, the AAV researchers are searching for AAV isolates and isotypes, which are not neutralized by the common pool of antibodies, but still offer the beneficial properties of the original virus [158-160]. In the case of a short protein with a single function as with the RBD of the VP1u, an immune escape by antigenic drift is easier to achieve without disturbing the receptor binding and internalization capacity. The natural mutations observed in various B19V isolates (Figure 3C) together with the mutational studies already performed [28], provide an excellent basis to mimic an antigenic drift of the VP1u RBD without decreasing the targeting function of the protein. Furthermore, there exist different options to reduce the antigenicity of a therapeutic protein, such as a fusion with an abundant endogenous protein as serum albumin or the immunoglobulin constant fragments [161-163]. The coupling to these endogenous proteins does not only circumvent the immune response, but also considerably increases the solubility, stability, and serum half-life of the therapeutic proteins. In line with this concept, bovine serum albumin (BSA) was used as an adaptor molecule for the attachment of the toxins to a VP1u-NeutrAvidin complex. The results showed that the modified BSA remained soluble after the attachment of 20-30 fluorescein or toxin molecules to the protein and was targeted exclusively to VP1u-expressing cells. The stability of the drug attachment might be increased by packing the effector molecule into a capsid, as shown with the MS2 bacteriophage in previous studies $[145,146,164]$. The specific delivery of an encapsidated effector allows a higher dose per delivered particle without increasing toxicity. Besides, the capsid can be engineered to incorporate multiple residues to improve the targeting efficiency. 


\section{Concluding Remarks}

The VP1u is a key component of the capsid of human parvovirus B19 with essential functions in multiple steps of the infection, such as tissue tropism, uptake, intracellular trafficking, and entry. The VP1u is also the immunodominant region of the capsid and a crucial component for prospective vaccines. In the future, efforts will be focused to better understand the essential functions of VP1u in B19V infection and to identify the VP1u interactome, notably its cognate cell receptor.

Recent innovations in protein engineering and nanomaterials science have the potential to revolutionize the conventional methods of diagnosis and treatment, bringing new hopes to patients. However, to date, a major barrier in their clinical application remains their poor selective targeting. Only a few clinically approved nanoscale delivery vehicles integrate molecules to selectively target the cargo to the tissue of interest. In this regard, the remarkable erythroid specificity of the VP1u offers novel opportunities to generate virus-inspired biomarkers and nanocarriers to specifically target erythroid cells. This approach may contribute to a better understanding of the mechanisms governing erythroid development and to treat disorders of the erythroid lineage. Efforts to circumvent the VP1u immune response and to optimize the stability and density of cargo delivery will facilitate its transferability to human diagnostics and therapies.

Author Contributions: Conceptualization, R.L. and C.R.; writing-original draft preparation, C.R.; review and editing, R.L., J.B. and C.R.; Supervision, funding acquisition, C.R. All authors have read and agreed to the published version of the manuscript.

Funding: This work was supported by the Swiss National Science Foundation (grant number 31003A_179384) to J.B.

Conflicts of Interest: The authors declare no conflict of interest.

\section{References}

1. Cotmore, S.F; Tattersall, P. Parvoviruses: Small does not mean simple. Annu. Rev. Virol. 2014, 1, 517-537. [CrossRef] [PubMed]

2. Kailasan, S.; Agbandje-Mckenna, M.; Parrish, C.R. Parvovirus Family Conundrum: What Makes a Killer? Annu. Rev. Virol. 2015, 2, 425-450. [CrossRef] [PubMed]

3. François, S.; Filloux, D.; Roumagnac, P.; Bigot, D.; Gayral, P.; Martin, D.P.; Froissart, R.; Ogliastro, M. Discovery of parvovirus-related sequences in an unexpected broad range of animals. Sci. Rep. 2016, 6, 1-13. [CrossRef] [PubMed]

4. Cotmore, S.F.; Agbandje-McKenna, M.; Canuti, M.; Chiorini, J.A.; Eis-Hubinger, A.M.; Hughes, J.; Mietzsch, M.; Modha, S.; Ogliastro, M.; Pénzes, J.J.; et al. ICTV virus taxonomy profile: Parvoviridae. J. Gen. Virol. 2019, 100, 367-368. [CrossRef] [PubMed]

5. Samulski, R.J.; Muzyczka, N. AAV-mediated gene therapy for research and therapeutic purposes. Annu. Rev. Virol. 2014, 1, 427-451. [CrossRef] [PubMed]

6. Cotmore, S.F.; Tattersall, P. Characterization and molecular cloning of a human parvovirus genome. Science 1984, 226, 1161-1165. [CrossRef]

7. Cotmore, S.F.; Tattersall, P. DNA replication in the autonomous parvoviruses. Semin. Virol. 1995, 6, 271-281. [CrossRef]

8. Tattersall, P.; Cawte, P.J.; Shatkin, A.J.; Ward, D.C. Three structural polypeptides coded for by minite virus of mice, a parvovirus. J. Virol. 1976, 20, 273-289. [CrossRef]

9. Becerra, S.P.; Koczot, F.; Fabisch, P.; Rose, J.A. Synthesis of adeno-associated virus structural proteins requires both alternative mRNA splicing and alternative initiations from a single transcript. J. Virol. 1988, 62, 2745-2754. [CrossRef]

10. Mani, B.; Baltzer, C.; Valle, N.; Almendral, J.M.; Kempf, C.; Ros, C. Low pH-dependent endosomal processing of the incoming parvovirus minute virus of mice virion leads to externalization of the VP1 N-terminal sequence (N-VP1), N-VP2 cleavage, and uncoating of the full-length genome. J. Virol. 2006, 80, 1015-1024. [CrossRef] 
11. Mietzsch, M.; Pénzes, J.J.; Agbandje-Mckenna, M. Twenty-five years of structural parvovirology. Viruses 2019, 11, 362. [CrossRef] [PubMed]

12. Vihinen-Ranta, M.; Kakkola, L.; Kalela, A.; Vilja, P.; Vuento, M. Characterization of a nuclear localization signal of canine parvovirus capsid proteins. Eur. J. Biochem. 1997, 250, 389-394. [CrossRef] [PubMed]

13. Lombardo, E.; Ramírez, J.C.; Garcia, J.; Almendral, J.M. Complementary Roles of Multiple Nuclear Targeting Signals in the Capsid Proteins of the Parvovirus Minute Virus of Mice during Assembly and Onset of Infection. J. Virol. 2002, 76, 7049-7059. [CrossRef] [PubMed]

14. Vihinen-Ranta, M.; Wang, D.; Weichert, W.S.; Parrish, C.R. The VP1 N-Terminal Sequence of Canine Parvovirus Affects Nuclear Transport of Capsids and Efficient Cell Infection. J. Virol. 2002, 76, 1884-1891. [CrossRef] [PubMed]

15. Grieger, J.C.; Snowdy, S.; Samulski, R.J. Separate Basic Region Motifs within the Adeno-Associated Virus Capsid Proteins Are Essential for Infectivity and Assembly. J. Virol. 2006, 80, 5199-5210. [CrossRef] [PubMed]

16. Sonntag, F.; Bleker, S.; Leuchs, B.; Fischer, R.; Kleinschmidt, J.A. Adeno-Associated Virus Type 2 Capsids with Externalized VP1/VP2 Trafficking Domains Are Generated prior to Passage through the Cytoplasm and Are Maintained until Uncoating Occurs in the Nucleus. J. Virol. 2006, 80, 11040-11054. [CrossRef] [PubMed]

17. Li, Q.; Zhang, Z.; Zheng, Z.; Ke, X.; Luo, H.; Hu, Q.; Wang, H. Identification and characterization of complex dual nuclear localization signals in human bocavirus NP1. J. Gen. Virol. 2013, 94, 1335-1342. [CrossRef]

18. Boisvert, M.; Bouchard-Levesque, V.; Fernandes, S.; Tijssen, P. Classic Nuclear Localization Signals and a Novel Nuclear Localization Motif Are Required for Nuclear Transport of Porcine Parvovirus Capsid Proteins. J. Virol. 2014, 88, 11748-11759. [CrossRef]

19. Liu, P.; Chen, S.; Wang, M.; Cheng, A. The role of nuclear localization signal in parvovirus life cycle. Virol. J. 2017, 14, 17-22. [CrossRef]

20. Li, Y.; Zádori, Z.; Bando, H.; Dubuc, R.; Fédière, G.; Szelei, J.; Tijssen, P. Genome organization of the densovirus from Bombyx mori (BmDNV-1) and enzyme activity of its capsid. J. Gen. Virol. 2001, 82, 2821-2825. [CrossRef]

21. Zádori, Z.; Szelei, J.; Lacoste, M.C.; Li, Y.; Gariépy, S.; Raymond, P.; Allaire, M.; Nabi, I.R.; Tijssen, P. A Viral Phospholipase A2 Is Required for Parvovirus Infectivity. Dev. Cell 2001, 1, 291-302. [CrossRef]

22. Dorsch, S.; Liebisch, G.; Kaufmann, B.; von Landenberg, P.; Hoffmann, J.H.; Drobnik, W.; Modrow, S. The VP1 Unique Region of Parvovirus B19 and Its Constituent Phospholipase A2-Like Activity. J. Virol. 2002, 76, 2014-2018. [CrossRef] [PubMed]

23. Girod, A.; Wobus, C.E.; Zádori, Z.; Ried, M.; Leike, K.; Tijssen, P.; Kleinschmidt, J.A.; Hallek, M. The VP1 capsid protein of adeno-associated virus type 2 is carrying a phospholipase A2 domain required for virus infectivity. J. Gen. Virol. 2002, 83, 973-978. [CrossRef] [PubMed]

24. Farr, G.A.; Zhang, L.G.; Tattersall, P. Parvoviral virions deploy a capsid-tethered lipolytic enzyme to breach the endosomal membrane during cell entry. Proc. Natl. Acad. Sci. USA 2005, 102, 17148-17153. [CrossRef] [PubMed]

25. Qu, X.W.; Liu, W.P.; Qi, Z.Y.; Duan, Z.J.; Zheng, L.S.; Kuang, Z.Z.; Zhang, W.J.; Hou, Y. De Phospholipase A2-like activity of human bocavirus VP1 unique region. Biochem. Biophys. Res. Commun. 2008, 365, 158-163. [CrossRef] [PubMed]

26. Stahnke, S.; Lux, K.; Uhrig, S.; Kreppel, F.; Hösel, M.; Coutelle, O.; Ogris, M.; Hallek, M.; Büning, H. Intrinsic phospholipase A2 activity of adeno-associated virus is involved in endosomal escape of incoming particles. Virology 2011, 409, 77-83. [CrossRef]

27. Popa-Wagner, R.; Porwal, M.; Kann, M.; Reuss, M.; Weimer, M.; Florin, L.; Kleinschmidt, J.A. Impact of VP1-Specific Protein Sequence Motifs on Adeno-Associated Virus Type 2 Intracellular Trafficking and Nuclear Entry. J. Virol. 2012, 86, 9163-9174. [CrossRef]

28. Leisi, R.; Di Tommaso, C.; Kempf, C.; Ros, C. The receptor-binding domain in the VP1u region of parvovirus B19. Viruses 2016, 8, 61. [CrossRef]

29. Harbison, C.E.; Chiorini, J.A.; Parrish, C.R. The parvovirus capsid odyssey: From the cell surface to the nucleus. Trends Microbiol. 2008, 16, 208-214. [CrossRef]

30. Ros, C.; Bayat, N.; Wolfisberg, R.; Almendral, J.M. Protoparvovirus cell entry. Viruses 2017, 9, 313. [CrossRef]

31. Kronenberg, S.; Böttcher, B.; von der Lieth, C.W.; Bleker, S.; Kleinschmidt, J.A. A Conformational Change in the Adeno-Associated Virus Type 2 Capsid Leads to the Exposure of Hidden VP1 N Termini. J. Virol. 2005, 79, 5296-5303. [CrossRef] [PubMed] 
32. Bönsch, C.; Zuercher, C.; Lieby, P.; Kempf, C.; Ros, C. The Globoside Receptor Triggers Structural Changes in the B19 Virus Capsid That Facilitate Virus Internalization. J. Virol. 2010, 84, 11737-11746. [CrossRef] [PubMed]

33. Tsao, J.; Chapman, M.S.; Agbandje, M.; Keller, W.; Smith, K.; Wu, H.; Luo, M.; Smith, T.J.; Rossmann, M.G.; Compans, R.W.; et al. The three-dimensional structure of canine parvovirus and its functional implications. Science 1991, 251, 1456-1464. [CrossRef] [PubMed]

34. Chapman, M.S.; Rossmann, M.G. Structure, sequence, and function correlations among parvoviruses. Virology 1993, 194, 491-508. [CrossRef]

35. Llamas-Saiz, A.L.; Agbandje-McKenna, M.; Wikoff, W.R.; Bratton, J.; Tattersall, P.; Rossmann, M.G. Structure determination of minute virus of mice. Acta Crystallogr. Sect. D Biol. Crystallogr. 1997, 53, 93-102. [CrossRef] [PubMed]

36. Kaufmann, B.; Simpson, A.A.; Rossmann, M.G. The structure of human parvovirus B19. Proc. Natl. Acad. Sci. USA 2004, 101, 11628-11633. [CrossRef]

37. Agbandje-McKenna, M.; Llamas-Saiz, A.L.; Wang, F.; Tattersall, P.; Rossmann, M.G. Functional implications of the structure of the murine parvovirus, minute virus of mice. Structure 1998, 6, 1369-1381. [CrossRef]

38. Bleker, S.; Sonntag, F.; Kleinschmidt, J.A. Mutational Analysis of Narrow Pores at the Fivefold Symmetry Axes of Adeno-Associated Virus Type 2 Capsids Reveals a Dual Role in Genome Packaging and Activation of Phospholipase A2 Activity. J. Virol. 2005, 79, 2528-2540. [CrossRef]

39. Farr, G.A.; Cotmore, S.F.; Tattersall, P. VP2 Cleavage and the Leucine Ring at the Base of the Fivefold Cylinder Control pH-Dependent Externalization of both the VP1 N Terminus and the Genome of Minute Virus of Mice. J. Virol. 2006, 80, 161-171. [CrossRef]

40. Plevka, P.; Hafenstein, S.; Li, L.; D’Abrgamo, A.; Cotmore, S.F.; Rossmann, M.G.; Tattersall, P. Structure of a Packaging-Defective Mutant of Minute Virus of Mice Indicates that the Genome Is Packaged via a Pore at a 5-Fold Axis. J. Virol. 2011, 85, 4822-4827. [CrossRef]

41. Castellanos, M.; Pérez, R.; Rodríguez-Huete, A.; Grueso, E.; Almendral, J.M.; Mateu, M.G. A slender tract of glycine residues is required for translocation of the VP2 protein N-terminal domain through the parvovirus MVM capsid channel to initiate infection. Biochem. J. 2013, 455, 87-94. [CrossRef] [PubMed]

42. Farr, G.A.; Tattersall, P. A conserved leucine that constricts the pore through the capsid fivefold cylinder plays a central role in parvoviral infection. Virology 2004, 323, 243-256. [CrossRef] [PubMed]

43. Cotmore, S.F.; Tattersall, P. Mutations at the Base of the Icosahedral Five-Fold Cylinders of Minute Virus of Mice Induce 3'-to-5' Genome Uncoating and Critically Impair Entry Functions. J. Virol. 2012, 86, 69-80. [CrossRef] [PubMed]

44. Ros, C.; Gerber, M.; Kempf, C. Conformational changes in the VP1-unique region of native human parvovirus B19 lead to exposure of internal sequences that play a role in virus neutralization and infectivity. J. Virol. 2006, 80, 12017-12024. [CrossRef] [PubMed]

45. Qiu, J.; Söderlund-Venermo, M.; Young, N.S. Human Parvoviruses. Clin. Microbiol. Rev. 2017, 30, $43-113$. [CrossRef] [PubMed]

46. Vassilopoulos, D.; Calabrese, L.H. Virally associated arthritis 2008: Clinical, epidemiologic, and pathophysiologic considerations. Arthritis Res. Ther. 2008, 10, 1-8. [CrossRef]

47. Heegaard, E.D.; Brown, K.E. Human Parvovirus B19. Clin. Microbiol. Rev. 2002, 15, 485-505. [CrossRef]

48. Bonvicini, F.; Bua, G.; Gallinella, G. Parvovirus B19 infection in pregnancy-Awareness and opportunities. Curr. Opin. Virol. 2017, 27, 8-14. [CrossRef]

49. Cossart, Y.E.; Cant, B.; Field, A.M.; Widdows, D. Parvovirus-Like Particles in Human Sera. Lancet 1975, 305, 72-73. [CrossRef]

50. Christensen, A.; Kesti, O.; Elenius, V.; Eskola, A.L.; Døllner, H.; Altunbulakli, C.; Akdis, C.A.; Söderlund-Venermo, M.; Jartti, T. Human bocaviruses and paediatric infections. Lancet Child Adolesc. Health 2019, 3, 418-426. [CrossRef]

51. Söderlund-Venermo, M. Emerging Human Parvoviruses: The Rocky Road to Fame. Annu. Rev. Virol. 2019, 6, 71-91. [CrossRef] [PubMed]

52. Ozawa, K.; Kurtzman, G.; Young, N. Replication of the B19 parvovirus in human bone marrow cell cultures. Science 1986, 233, 883-886. [CrossRef] [PubMed]

53. Takahashi, T.; Ozawa, K.; Takahashi, K.; Asano, S.; Takaku, F. Susceptibility of human erythropoietic cells to B19 parvovirus in vitro increases with differentiation. Blood 1990, 75, 603-610. [CrossRef] [PubMed] 
54. Leisi, R.; Ruprecht, N.; Kempf, C.; Ros, C. Parvovirus B19 uptake is a highly selective process controlled by VP1u, a novel determinant of viral tropism. J. Virol. 2013, 87, 13161-13167. [CrossRef]

55. Guan, W.; Cheng, F.; Yoto, Y.; Kleiboeker, S.; Wong, S.; Zhi, N.; Pintel, D.J.; Qiu, J. Block to the Production of Full-Length B19 Virus Transcripts by Internal Polyadenylation Is Overcome by Replication of the Viral Genome. J. Virol. 2008, 82, 9951-9963. [CrossRef]

56. Wong, S.; Zhi, N.; Filippone, C.; Keyvanfar, K.; Kajigaya, S.; Brown, K.E.; Young, N.S. Ex Vivo-Generated CD36+ Erythroid Progenitors Are Highly Permissive to Human Parvovirus B19 Replication. J. Virol. 2008, 82, 2470-2476. [CrossRef]

57. Chen, A.Y.; Guan, W.; Lou, S.; Liu, Z.; Kleiboeker, S.; Qiu, J. Role of Erythropoietin Receptor Signaling in Parvovirus B19 Replication in Human Erythroid Progenitor Cells. J. Virol. 2010, 84, 12385-12396. [CrossRef]

58. Wolfisberg, R.; Ruprecht, N.; Kempf, C.; Ros, C. Impaired genome encapsidation restricts the in vitro propagation of human parvovirus B19. J. Virol. Methods 2013, 193, 215-225. [CrossRef]

59. Leisi, R.; Nordheim, M.V.; Ros, C.; Kempf, C. The VP1u receptor restricts parvovirus B19 uptake to permissive erythroid cells. Viruses 2016, 8, 265. [CrossRef]

60. Gallinella, G.; Manaresi, E.; Zuffi, E.; Venturoli, S.; Bonsi, L.; Bagnara, G.P.; Musiani, M.; Zerbini, M. Different patterns of restriction to B19 parvovirus replication in human blast cell lines. Virology 2000, 278, 361-367. [CrossRef]

61. Ganaie, S.S.; Qiu, J. Recent advances in replication and infection of human parvovirus B19. Front. Cell. Infect. Microbiol. 2018, 8, 1-12. [CrossRef] [PubMed]

62. Luo, Y.; Qiu, J. Human parvovirus B19: A mechanistic overview of infection and DNA replication. Future Virol. 2015, 10, 155-167. [CrossRef] [PubMed]

63. Stramer, S.L.; Dodd, R.Y. Transfusion-transmitted emerging infectious diseases: 30 years of challenges and progress. Transfusion 2013, 53, 2375-2383. [CrossRef] [PubMed]

64. Deiss, V.; Tratschin, J.D.; Weitz, M.; Siegl, G. Cloning of the human parvovirus B19 genome and structural analysis of its palindromic termini. Virology 1990, 175, 247-254. [CrossRef]

65. Cotmore, S.F.; McKie, V.C.; Anderson, L.J.; Astell, C.R.; Tattersall, P. Identification of the major structural and nonstructural proteins encoded by human parvovirus B19 and mapping of their genes by procaryotic expression of isolated genomic fragments. J. Virol. 1986, 60, 548-557. [CrossRef] [PubMed]

66. Kaufmann, B.; Chipman, P.R.; Kostyuchenko, V.A.; Modrow, S.; Rossmann, M.G. Visualization of the Externalized VP2 N Termini of Infectious Human Parvovirus B19. J. Virol. 2008, 82, 7306-7312. [CrossRef]

67. Saikawa, T.; Anderson, S.; Momoeda, M.; Kajigaya, S.; Young, N.S. Neutralizing linear epitopes of B19 parvovirus cluster in the VP1 unique and VP1-VP2 junction regions. J. Virol. 1993, 67, 3004-3009. [CrossRef]

68. Anderson, S.; Momoeda, M.; Kawase, M.; Kajigaya, S.; Young, N.S. Peptides derived from the unique region of B19 parvovirus minor capsid protein elicitneutralizing antibodies in rabbits. Virology 1995, 206, 626-632. [CrossRef]

69. Klasse, P.J.; Sattentau, Q.J. Occupancy and mechanism in antibody-mediated neutralization of animal viruses. J. Gen. Virol. 2002, 83, 2091-2108. [CrossRef]

70. Klasse, P.J. Neutralization of Virus Infectivity by Antibodies: Old Problems in New Perspectives. Adv. Biol. 2014, 2014, 157895. [CrossRef]

71. Burton, D.R. Antibodies, viruses and vaccines. Nat. Rev. Immunol. 2002, 2, 706-713. [CrossRef] [PubMed]

72. Modrow, S.; Dorsch, S. Antibody responses in parvovirus B19 infected patients. Pathol. Biol. 2002, 50, 326-331. [CrossRef]

73. Kurtzman, G.J.; Cohen, B.J.; Field, A.M.; Oseas, R.; Blaese, R.M.; Young, N.S. Immune response to B19 parvovirus and an antibody defect in persistent viral infection. J. Clin. Investig. 1989, 84, 1114-1123. [CrossRef] [PubMed]

74. Kurtzman, G.; Frickhofen, N.; Kimball, J.; Jenkins, D.W.; Nienhuis, A.W.; Young, N.S. Pure Red-Cell Aplasia of 10 Years' Duration Due to Persistent Parvovirus B19 Infection and Its Cure with Immunoglobulin Therapy. N. Engl. J. Med. 1989, 321, 519-523. [CrossRef] [PubMed]

75. Bernstein, D.I.; El Sahly, H.M.; Keitel, W.A.; Wolff, M.; Simone, G.; Segawa, C.; Wong, S.; Shelly, D.; Young, N.S.; Dempsey, W. Safety and immunogenicity of a candidate parvovirus B19 vaccine. Vaccine 2011, 29, 7357-7363. [CrossRef] 
76. Chandramouli, S.; Medina-Selby, A.; Coit, D.; Schaefer, M.; Spencer, T.; Brito, L.A.; Zhang, P.; Otten, G.; Mandl, C.W.; Mason, P.W.; et al. Generation of a parvovirus B19 vaccine candidate. Vaccine 2013, 31, 3872-3878. [CrossRef]

77. Bua, G.; Manaresi, E.; Bonvicini, F.; Gallinella, G. Parvovirus B19 Replication and Expression in Differentiating Erythroid Progenitor Cells. PLoS ONE 2016, 11, 1-19. [CrossRef]

78. Brown, K.E.; Anderson, S.M.; Young, N.S. Erythrocyte P antigen: Cellular receptor for B19 parvovirus. Science 1993, 262, 114-117. [CrossRef]

79. Brown, K.E.; Cohen, B.J. Haemagglutination by parvovirus B19. J. Gen. Virol. 1992, 73, 2147-2149. [CrossRef]

80. Brown, K.E.; Hibbs, J.R.; Gallinella, G.; Anderson, S.M.; Lehman, E.D.; McCarthy, P.; Young, N.S. Resistance to parvovirus B19 infection due to lack of virus receptor (erythrocyte P antigen). N. Engl. J. Med. 1994, 330, 1192-1196. [CrossRef]

81. Chipman, P.R.; Agbandje-Mckenna, M.; Kajigaya, S.; Brown, K.E.; Young, N.S.; Baker, T.S.; Rossmann, M.G. Cryo-electron microscopy studies of empty capsids of human parvovirus B19 complexed with its cellular receptor. Proc. Natl. Acad. Sci. USA 1996, 93, 7502-7506. [CrossRef] [PubMed]

82. Nasir, W.; Nilsson, J.; Olofsson, S.; Bally, M.; Rydell, G.E. Parvovirus B19 VLP recognizes globoside in supported lipid bilayers. Virology 2014, 456-457, 364-369. [CrossRef] [PubMed]

83. Weigel-Kelley, K.A.; Yoder, M.C.; Srivastava, A. Recombinant Human Parvovirus B19 Vectors: Erythrocyte P Antigen Is Necessary but Not Sufficient for Successful Transduction of Human Hematopoietic Cells. J. Virol. 2001, 75, 4110-4116. [CrossRef] [PubMed]

84. Bieri, J.; Ros, C. Globoside Is Dispensable for Parvovirus B19 Entry but Essential at a Postentry Step for Productive Infection. J. Virol. 2019, 93, 1-15. [CrossRef]

85. Weigel-Kelley, K.A.; Yoder, M.C.; Srivastava, A. $\alpha 5 \beta 1$ integrin as a cellular coreceptor for human parvovirus B19: Requirement of functional activation of $\beta 1$ integrin for viral entry. Blood 2003, 102, 3927-3933. [CrossRef] [PubMed]

86. Munakata, Y.; Saito-Ito, T.; Kumura-Ishii, K.; Huang, J.; Kodera, T.; Ishii, T.; Hirabayashi, Y.; Koyanagi, Y.; Sasaki, T. Ku80 autoantigen as a cellular coreceptor for human parvovirus B19 infection. Blood 2005, 106, 3449-3456. [CrossRef]

87. Bönsch, C.; Kempf, C.; Ros, C. Interaction of parvovirus B19 with human erythrocytes alters virus structure and cell membrane integrity. J. Virol. 2008, 82, 11784-11791. [CrossRef]

88. Xu, D.; Zhang, Y. Ab initio protein structure assembly using continuous structure fragments and optimized knowledge-based force field. Proteins Struct. Funct. Bioinform. 2012, 80, 1715-1735. [CrossRef]

89. Shimomura, S.; Komatsu, N.; Frickhofen, N.; Anderson, S.; Kajigaya, S.; Young, N.S. First continuous propagation of B19 parvovirus in a cell line. Blood 1992, 79, 18-24. [CrossRef]

90. Miyagawa, E.; Yoshida, T.; Takahashi, H.; Yamaguchi, K.; Nagano, T.; Kiriyama, Y.; Okochi, K.; Sato, H. Infection of the erythroid cell line, KU812Ep6 with human parvovirus B19 and its application to titration of B19 infectivity. J. Virol. Methods 1999, 83, 45-54. [CrossRef]

91. Koury, M.J.; Bondurant, M.C. Maintenance by erythropoietin of viability and maturation of murine erythroid precursor cells. J. Cell. Physiol. 1988, 137, 65-74. [CrossRef] [PubMed]

92. Koury, M.J.; Bondurant, M.C. Erythropoietin retards DNA breakdown and prevents programmed death in erythroid progenitor cells. Science 1990, 248, 378-381. [CrossRef] [PubMed]

93. Pop, R.; Shearstone, J.R.; Shen, Q.; Liu, Y.; Hallstrom, K.; Koulnis, M.; Gribnau, J.; Socolovsky, M. A key commitment step in erythropoiesis is synchronized with the cell cycle clock through mutual inhibition between PU.1 and S-phase progression. PLoS Biol. 2010, 8, e1000484. [CrossRef] [PubMed]

94. Chen, A.Y.; Kleiboeker, S.; Qiu, J. Productive parvovirus B19 infection of primary human erythroid progenitor cells at hypoxia is regulated by STAT5A and MEK signaling but not HIF $\alpha$. PLoS Pathog. 2011, 7, e1002088. [CrossRef]

95. Ganaie, S.S.; Zou, W.; Xu, P.; Deng, X.; Kleiboeker, S.; Qiu, J. Phosphorylated STAT5 directly facilitates parvovirus B19 DNA replication in human erythroid progenitors through interaction with the MCM complex. PLoS Pathog. 2017, 13, 1-27. [CrossRef]

96. An, X.; Schulz, V.P.; Li, J.; Wu, K.; Liu, J.; Xue, F.; Hu, J.; Mohandas, N.; Gallagher, P.G. Global transcriptome analyses of human and murine terminal erythroid differentiation. Blood 2014, 123, 3466-3477. [CrossRef]

97. Kerr, J.R.; Linden, M.R. Human dependovirus infection. In Parvoviruses; Hodder Arnold, Oxford University Press: London, UK, 2006; pp. 381-384. 
98. Guan, W.; Wong, S.; Zhi, N.; Qiu, J. The Genome of Human Parvovirus B19 Can Replicate in Nonpermissive Cells with the Help of Adenovirus Genes and Produces Infectious Virus. J. Virol. 2009, 83, 9541-9553. [CrossRef]

99. Winter, K.; von Kietzell, K.; Heilbronn, R.; Pozzuto, T.; Fechner, H.; Weger, S. Roles of E4orf6 and VA I RNA in Adenovirus-Mediated Stimulation of Human Parvovirus B19 DNA Replication and Structural Gene Expression. J. Virol. 2012, 86, 5099-5109. [CrossRef]

100. Doerig, C.; Hirt, B.; Antonietti, J.P.; Beard, P. Nonstructural protein of parvoviruses B19 and minute virus of mice controls transcription. J. Virol. 1990, 64, 387-396. [CrossRef]

101. Ponnazhagan, S.; Woody, M.J.; Wang, X.S.; Zhou, S.Z.; Srivastava, A. Transcriptional transactivation of parvovirus B19 promoters in nonpermissive human cells by adenovirus type 2. J. Virol. 1995, 69, 8096-8101. [CrossRef]

102. Ozawa, K.; Ayub, J.; Hao, Y.S.; Kurtzman, G.; Shimada, T.; Young, N. Novel transcription map for the B19 (human) pathogenic parvovirus. J. Virol. 1987, 61, 2395-2406. [CrossRef] [PubMed]

103. Von Kietzell, K.; Pozzuto, T.; Heilbronn, R.; Grössl, T.; Fechner, H.; Weger, S. Antibody-Mediated Enhancement of Parvovirus B19 Uptake into Endothelial Cells Mediated by a Receptor for Complement Factor C1q. J. Virol. 2014, 88, 8102-8115. [CrossRef] [PubMed]

104. Quattrocchi, S.; Ruprecht, N.; Bnsch, C.; Bieli, S.; Zürcher, C.; Boller, K.; Kempf, C.; Ros, C. Characterization of the early steps of human parvovirus B19 infection. J. Virol. 2012, 86, 9274-9284. [CrossRef]

105. Dennis, E.A.; Cao, J.; Hsu, Y.H.; Magrioti, V.; Kokotos, G. Phospholipase A2 enzymes: Physical structure, biological function, disease implication, chemical inhibition, and therapeutic intervention. Chem. Rev. 2011, 111, 6130-6185. [CrossRef] [PubMed]

106. Canaan, S.; Zádori, Z.; Ghomashchi, F.; Bollinger, J.; Sadilek, M.; Moreau, M.E.; Tijssen, P.; Gelb, M.H. Interfacial Enzymology of Parvovirus Phospholipases A2. J. Biol. Chem. 2004, 279, 14502-14508. [CrossRef]

107. Deng, X.; Dong, Y.; Yi, Q.; Huang, Y.; Zhao, D.; Yang, Y.; Tijssen, P.; Qiu, J.; Liu, K.; Li, Y. The Determinants for the Enzyme Activity of Human Parvovirus B19 Phospholipase A2 (PLA2) and Its Influence on Cultured Cells. PLoS ONE 2013, 8, e61440. [CrossRef]

108. Lupescu, A.; Bock, C.-T.; Lang, P.A.; Aberle, S.; Kaiser, H.; Kandolf, R.; Lang, F. Phospholipase A2 Activity-Dependent Stimulation of Ca2+ Entry by Human Parvovirus B19 Capsid Protein VP1. J. Virol. 2006, 80, 11370-11380. [CrossRef]

109. Almilaji, A.; Szteyn, K.; Fein, E.; Pakladok, T.; Munoz, C.; Elvira, B.; Towhid, S.T.; Alesutan, I.; Shumilina, E.; Bock, C.T.; et al. Down-regulation of $\mathrm{Na} / \mathrm{K}+$ ATPase activity by human parvovirus B19 capsid protein VP1. Cell. Physiol. Biochem. 2013, 31, 638-648. [CrossRef]

110. Ahmed, M.; Almilaji, A.; Munoz, C.; Elvira, B.; Shumilina, E.; Bock, C.T.; Kandolf, R.; Lang, F. Down-regulation of $\mathrm{K}+$ channels by human parvovirus B19 capsid protein VP1. Biochem. Biophys. Res. Commun. 2014, 450, 1396-1401. [CrossRef]

111. Ahmed, M.; Honisch, S.; Pelzl, L.; Fezai, M.; Hosseinzadeh, Z.; Bock, C.T.; Kandolf, R.; Lang, F. Up-regulation of epithelial $\mathrm{Na}+$ channel ENaC by human parvovirus B19 capsid protein VP1. Biochem. Biophys. Res. Commun. 2015, 468, 179-184. [CrossRef]

112. Lu, J.; Zhi, N.; Wong, S.; Brown, K.E. Activation of Synoviocytes by the Secreted Phospholipase $A_{2}$ Motif in the VP1-Unique Region of Parvovirus B19 Minor Capsid Protein. J. Infect. Dis. 2006, 193, 582-590. [CrossRef] [PubMed]

113. Lange, A.; Mills, R.E.; Lange, C.J.; Stewart, M.; Devine, S.E.; Corbett, A.H. Classical nuclear localization signals: Definition, function, and interaction with importin $\alpha$. J. Biol. Chem. 2007, 282, 5101-5105. [CrossRef]

114. Panté, N.; Kann, M. Nuclear pore complex is able to transport macromolecules with diameters of $\sim 39 \mathrm{~nm}$. Mol. Biol. Cell 2002, 13, 425-434. [CrossRef] [PubMed]

115. Mäntylä, E.; Aho, V.; Kann, M.; Vihinen-Ranta, M. Cytoplasmic Parvovirus Capsids Recruit Importin Beta for Nuclear Delivery. J. Virol. 2020, 94, e01532-19. [CrossRef]

116. Pillet, S.; Annan, Z.; Fichelson, S.; Morinet, F. Identification of a nonconventional motif necessary for the nuclear import of the human parvovirus B19 major capsid protein (VP2). Virology 2003, 306, 25-32. [CrossRef]

117. Peer, D.; Karp, J.M.; Hong, S.; Farokhzad, O.C.; Margalit, R.; Langer, R. 84 Nat nanotech 2007 R Langer Nanocarriers as an emerging platform for cancer therapy.pdf. Nat. Nanotechnol. 2007, 2, 751-760. [CrossRef]

118. Wilhelm, S.; Tavares, A.; Dai, Q.; Ohta, S.; Audet, J.; Dvorak, H.F.; Chan, W.C.W. Analysis of nanoparticle delivery to tumours. Nat. Rev. Mater. 2016, 1, 16014. [CrossRef] 
119. Ma, Y.; Nolte, R.J.M.; Cornelissen, J.J.L.M. Virus-based nanocarriers for drug delivery. Adv. Drug Deliv. Rev. 2012, 64, 811-825. [CrossRef]

120. Somiya, M.; Liu, Q.; Kuroda, S. Current progress of virus-mimicking nanocarriers for drug delivery. Nanotheranostics 2017, 1, 415-429. [CrossRef]

121. Stachon, A.; Holland-Letz, T.; Krieg, M. High in-hospital mortality of intensive care patients with nucleated red blood cells in blood. Clin. Chem. Lab. Med. 2004, 42, 933-938. [CrossRef]

122. Stachon, A.; Kempf, R.; Holland-Letz, T.; Friese, J.; Becker, A.; Krieg, M. Daily monitoring of nucleated red blood cells in the blood of surgical intensive care patients. Clin. Chim. Acta 2006, 366, 329-335. [CrossRef] [PubMed]

123. Buttarello, M.; Plebani, M. Automated blood cell counts: State of the art. Am. J. Clin. Pathol. 2008, 130, 104-116. [CrossRef] [PubMed]

124. Koury, M.J. Abnormal erythropoiesis and the pathophysiology of chronic anemia. Blood Rev. 2014, $28,49-66$. [CrossRef] [PubMed]

125. Danise, P.; Maconi, M.; Barrella, F.; Di Palma, A.; Avino, D.; Rovetti, A.; Gioia, M.; Amendola, G. Evaluation of nucleated red blood cells in the peripheral blood of hematological diseases. Clin. Chem. Lab. Med. 2011, 50, 357-360. [CrossRef]

126. Buoro, S.; Vavassori, M.; Pipitone, S.; Benegiamo, A.; Lochis, E.; Fumagalli, S.; Falanga, A.; Marchetti, M.; Crippa, A.; Ottomano, C.; et al. Evaluation of nucleated red blood cell count by Sysmex XE-2100 in patients with thalassaemia or sickle cell anaemia and in neonates. Blood Transfus. 2015, 13, 588-594. [CrossRef]

127. Constantino, B.T.; Cogionis, B. Nucleated RBCs-Significance in the peripheral blood film. Lab. Med. 2000, 31, 223-229. [CrossRef]

128. Da Rin, G.; Vidali, M.; Balboni, F.; Benegiamo, A.; Borin, M.; Ciardelli, M.L.; Dima, F.; Di Fabio, A.; Fanelli, A.; Fiorini, F.; et al. Performance evaluation of the automated nucleated red blood cell count of five commercial hematological analyzers. Int. J. Lab. Hematol. 2017, 39, 663-670. [CrossRef]

129. Anagnostou, A.; Liu, Z.; Steiner, M.; Chin, K.; Lee, E.S.; Kessimian, N.; Noguchi, C.T. Erythropoietin receptor mRNA expression in human endothelial cells. Proc. Natl. Acad. Sci. USA 1994, 91, 3974-3978. [CrossRef]

130. Spivak, J.L. The anaemia of cancer: Death by a thousand cuts. Nat. Rev. Cancer 2005, 5, 543-555. [CrossRef]

131. Jelkmann, W.; Bohlius, J.; Hallek, M.; Sytkowski, A.J. The erythropoietin receptor in normal and cancer tissues. Crit. Rev. Oncol. Hematol. 2008, 67, 39-61. [CrossRef]

132. Chen, K.; Liu, J.; Heck, S.; Chasis, J.A.; An, X.; Mohandas, N. Resolving the distinct stages in erythroid differentiation based on dynamic changes in membrane protein expression during erythropoiesis. Proc. Natl. Acad. Sci. USA 2009, 106, 17413-17418. [CrossRef]

133. Hu, J.; Liu, J.; Xue, F.; Halverson, G.; Reid, M.; Guo, A.; Chen, L.; Raza, A.; Galili, N.; Jaffray, J.; et al. Isolation and functional characterization of human erythroblasts at distinct stages: Implications for understanding of normal and disordered erythropoiesis in vivo. Blood 2013, 121, 3246-3253. [CrossRef] [PubMed]

134. MacHherndl-Spandl, S.; Suessner, S.; Danzer, M.; Proell, J.; Gabriel, C.; Lauf, J.; Sylie, R.; Klein, H.U.; Béné, M.C.; Weltermann, A.; et al. Molecular pathways of early CD105-positive erythroid cells as compared with CD34-positive common precursor cells by flow cytometric cell-sorting and gene expression profiling. Blood Cancer J. 2013, 3, 1-13. [CrossRef]

135. Origa, R. $\beta$-Thalassemia. Genet. Med. 2017, 19, 609-619. [CrossRef] [PubMed]

136. Kato, G.J.; Piel, F.B.; Reid, C.D.; Gaston, M.H.; Ohene-Frempong, K.; Krishnamurti, L.; Smith, W.R.; Panepinto, J.A.; Weatherall, D.J.; Costa, F.F.; et al. Sickle cell disease. Nat. Rev. Dis. Prim. 2018, 4, 1-22. [CrossRef] [PubMed]

137. Bayanzay, K.; Alzoebie, L. Reducing the iron burden and improving survival in transfusion-dependent thalassemia patients: Current perspectives. J. Blood Med. 2016, 7, 159-169. [CrossRef] [PubMed]

138. Coates, T.D.; Wood, J.C. How we manage iron overload in sickle cell patients. Br. J. Haematol. 2017, 177, 703-716. [CrossRef]

139. Peters, C. Allogeneic Hematopoietic Stem Cell Transplantation to Cure Transfusion-Dependent Thalassemia: Timing Matters! Biol. Blood Marrow Transpl. 2018, 24, 1107-1108. [CrossRef]

140. Gluckman, G.; Cappelli, B.; Bernaudin, F.; Labopin, M.; Volt, F.; Carreras, J.; Pinto Simoes, B.; Ferster, A.; Dupont, S.; de la Fuente, J.; et al. Sickle cell disease: An international survey of results of HLA-identical sibling hematopoietic stem cell transplantation. Blood 2017, 129, 1548-1556. [CrossRef] 
141. Karponi, G.; Zogas, N. Gene therapy for beta-thalassemia: Updated perspectives. Appl. Clin. Genet. 2019, 12, 167-180. [CrossRef]

142. Lidonnici, M.R.; Ferrari, G. Gene therapy and gene editing strategies for hemoglobinopathies. Blood Cells Mol. Dis. 2018, 70, 87-101. [CrossRef] [PubMed]

143. Lino, C.A.; Harper, J.C.; Carney, J.P.; Timlin, J.A. Delivering crispr: A review of the challenges and approaches. Drug Deliv. 2018, 25, 1234-1257. [CrossRef] [PubMed]

144. Chery, J. RNA therapeutics: RNAi and antisense mechanisms and clinical applications. Postdr. J. 2016, 4, 35-50. [CrossRef] [PubMed]

145. Galaway, F.A.; Stockley, P.G. MS2 viruslike particles: A robust, semisynthetic targeted drug delivery platform. Mol. Pharm. 2013, 10, 59-68. [CrossRef] [PubMed]

146. Ashley, C.E.; Carnes, E.C.; Phillips, G.K.; Durfee, P.N.; Buley, M.D.; Lino, C.A.; Padilla, D.P.; Phillips, B.; Carter, M.B.; Willman, C.L.; et al. Cell-specific delivery of diverse cargos by bacteriophage MS2 virus-like particles. ACS Nano 2011, 5, 5729-5745. [CrossRef] [PubMed]

147. Nai, A.; Lidonnici, M.R.; Rausa, M.; Mandelli, G.; Pagani, A.; Silvestri, L.; Ferrari, G.; Camaschella, C. The second transferrin receptor regulates red blood cell production in mice. Blood 2015, 125, 1170-1179. [CrossRef]

148. Artuso, I.; Lidonnici, M.R.; Altamura, S.; Mandelli, G.; Pettinato, M.; Muckenthaler, M.U.; Silvestri, L.; Ferrari, G.; Camaschella, C.; Nai, A. Transferrin receptor 2 is a potential novel therapeutic target for $\beta$-thalassemia: Evidence from a murine model. Blood 2018, 132, 2286-2297. [CrossRef]

149. Casu, C.; Pettinato, M.; Liu, A.; Aghajan, M.; Lo Presti, V.; Lidonnici, M.R.; Munoz, K.A.; O’Hara, E.; Olivari, V.; Di Modica, S.M.; et al. Correcting $\beta$-thalassemia by combined therapies that restrict iron and modulate erythropoietin activity. Blood 2020, 136, 1968-1979. [CrossRef]

150. Lohani, N.; Bhargava, N.; Munshi, A.; Ramalingam, S. Pharmacological and molecular approaches for the treatment of $\beta$-hemoglobin disorders. J. Cell. Physiol. 2018, 233, 4563-4577. [CrossRef]

151. Hasserjian, R.P.; Zuo, Z.; Garcia, C.; Tang, G.; Kasyan, A.; Luthra, R.; Abruzzo, L.V.; Kantarjian, H.M.; Medeiros, L.J.; Wang, S.A. Acute erythroid leukemia: A reassessment using criteria refined in the $2008 \mathrm{WHO}$ classification. Blood 2010, 115, 1985-1992. [CrossRef]

152. Wickrema, A.; Crispino, J.D. Erythroid and megakaryocytic transformation. Oncogene 2007, 26, 6803-6815. [CrossRef] [PubMed]

153. Mazzella, F.M.; Kowal-Vern, A.; Atef Shrit, M.; Rector, J.T.; Cotelingam, J.D.; Schumacher, H.R. Effects of multidrug resistance gene expression in acute erythroleukemia. Mod. Pathol. 2000, 13, 407-413. [CrossRef] [PubMed]

154. Schwartz, R.S. Paul Ehrlich's magic bullets. N. Engl. J. Med. 2004, 350, 1079-1080. [CrossRef]

155. Boddu, P.; Benton, C.B.; Wang, W.; Borthakur, G.; Khoury, J.D.; Pemmaraju, N. Erythroleukemia-historical perspectives and recent advances in diagnosis and management. Blood Rev. 2018, 32, 96-105. [CrossRef] [PubMed]

156. Leisi, R.; Von Nordheim, M.; Kempf, C.; Ros, C. Specific targeting of proerythroblasts and erythroleukemic cells by the VP1u region of parvovirus B19. Bioconjug. Chem. 2015, 26, 1923-1930. [CrossRef]

157. Rapti, K.; Louis-Jeune, V.; Kohlbrenner, E.; Ishikawa, K.; Ladage, D.; Zolotukhin, S.; Hajjar, R.J.; Weber, T. Neutralizing antibodies against AAV serotypes 1, 2, 6, and 9 in sera of commonly used animal models. Mol. Ther. 2012, 20, 73-83. [CrossRef]

158. Rutledge, E.A.; Halbert, C.L.; Russell, D.W. Infectious Clones and Vectors Derived from Adeno-Associated Virus (AAV) Serotypes Other Than AAV Type 2. J. Virol. 1998, 72, 309-319. [CrossRef]

159. Gao, G.; Vandenberghe, L.H.; Alvira, M.R.; Lu, Y.; Calcedo, R.; Zhou, X.; Wilson, J.M. Clades of Adeno-Associated Viruses Are Widely Disseminated in Human Tissues. J. Virol. 2004, 78, 6381-6388. [CrossRef]

160. Zinn, E.; Pacouret, S.; Khaychuk, V.; Turunen, H.T.; Carvalho, L.S.; Andres-Mateos, E.; Shah, S.; Shelke, R.; Maurer, A.C.; Maurer, E.; et al. In silico reconstruction of the viral evolutionary lineage yields a potent gene therapy vector. Cell Rep. 2015, 12, 1056-1068. [CrossRef]

161. Yeh, P.; Landais, D.; Lemaître, M.; Maury, I.; Crenne, J.Y.; Becquart, J.; Murry-Brelier, A.; Boucher, F.; Montay, G.; Fleer, R.; et al. Design of yeast-secreted albumin derivatives for human therapy: Biological and antiviral properties of a serum albumin-CD4 genetic conjugate. Proc. Natl. Acad. Sci. USA 1992, 89, 1904-1908. [CrossRef] 
162. Czajkowsky, D.M.; Hu, J.; Shao, Z.; Pleass, R.J. Fc-fusion proteins: New developments and future perspectives. EMBO Mol. Med. 2012, 4, 1015-1028. [CrossRef] [PubMed]

163. Shen, B.Q.; Xu, K.; Liu, L.; Raab, H.; Bhakta, S.; Kenrick, M.; Parsons-Reponte, K.L.; Tien, J.; Yu, S.F.; Mai, E.; et al. Conjugation site modulates the in vivo stability and therapeutic activity of antibody-drug conjugates. Nat. Biotechnol. 2012, 30, 184-189. [CrossRef] [PubMed]

164. Wu, M.; Brown, W.L.; Stockley, P.G. Cell-Specific Delivery of Bacteriophage-Encapsidated Ricin a Chain. Bioconjug. Chem. 1995, 6, 587-595. [CrossRef] [PubMed]

Publisher's Note: MDPI stays neutral with regard to jurisdictional claims in published maps and institutional affiliations.

(C) 2020 by the authors. Licensee MDPI, Basel, Switzerland. This article is an open access article distributed under the terms and conditions of the Creative Commons Attribution (CC BY) license (http://creativecommons.org/licenses/by/4.0/). 